\title{
A TURBÓKOMPRESSZOROK HÜTÉSÉBŐL KELETKEZŐ HULLADÉKHŐ HASZNOSÍTÁSA
}

\section{RECOVERY OF WASTE HEAT RESULTING FROM TURBOCOMPRESSOR COOLING}

\author{
Dósa János, ${ }^{1}$ Tomuș Ovidiu Bogdan ${ }^{2}$ \\ Petrozsényi Egyetem, Gépész- és Villamosmérnöki Kar, Gépészeti, Ipari és Közlekedésmérnöki Tanszék, \\ Petrozsény, Románia \\ ${ }^{1}$ __dosa@hotmail.com \\ ${ }^{2}$ tobogdan2002@yahoo.com
}

\begin{abstract}
Turbocompressors have high efficiency, and that make them ideal to supply larger mines with compressed air. As the gas flows through the compressor and the pressure increases, it is also heated, which means that a large amount of heat can be generated in the turbocompressor due to the high output of compressed air. Large amounts of heat need to be removed, which is usually done through cooling towers. The heat ultimately will end into the surroundings as waste heat. This article aims to study the recovery and possible use of this waste heat.
\end{abstract}

Keywords: turbocompressor, waste heat, heat recovery.

\section{Összefoglalás}

A turbókompresszorokat, azok nagy hozama miatt előszeretettel használják a nagyobb bányák sűrített levegővel való ellátására. Amikor a gáz átáramlik a kompresszoron és nyomása megnő, ezzel együtt fel is melegszik, tehát a nagy sürítettlevegő-hozama miatt sok hő keletkezhet a turbókompresszorban. A nagy menynyiségű hőt el kell távolítani, ami általában hűtőtornyok segítségével történik. Jelen közleményben ennek a hőnek a hasznosítását vizsgáljuk.

Kulcsszavak: turbókompresszor, hulladékhő, hasznosítás.

\section{Bevezetés}

A modern világ energiahiánnyal küzd, ezért világszerte aktuális téma az energiatakarékosság, illetve a hulladékhő hasznosítása.

Ennek jelentőségét az is mutatja, hogy az Európai Unió kiemelten foglalkozik a témával [1], de az Amerikai Egyesült Államokban is fontos problémakör [2], mi több, ugyanabban a kategóriában kezelik a környezetvédelemmel, és majdnem minden ország stratégiákat dolgozott ki ezen a területen [3, 4].

A hulladékhő hasznosítására nagy figyelmet fordítanak más országban is, és útmutatókat dol- goztak ki [5, 6], ezzel is segítve azoknak, akik komolyan veszik az energiatakarékosságot és a hulladékhő-hasznosítást.

Ezek az útmutatók a hulladékhőt a hőmérséklet alapján osztályozzák, de iparágak szerinti osztályozás is létezik, és a különféle tapasztalatok alapján a leghatékonyabb hasznosítási módszereket javasolják [7].

A fent említett forrásokra hivatkozva a bányákat inkább az alacsony hőmérsékletü hulladékhőforrások közé lehet sorolni, így a hő hasznosításának leghatékonyabb módja a hőszivattyúk használata. 


\section{A turbókompresszor használata a bányaiparban}

Bár a modern kompresszorok általában csavarkompresszorok, a nagy sürítettlevegő-hozamuk miatt a turbókompresszorokat is előszeretettel használják ott, ahol megszakítás nélkül kell sürített levegőt előállítani.

Ezen kívül a turbókompresszor jól alkalmazkodik a változó sűrítettlevegő-igényre, mivel a turbókompresszor jelleggörbéjén a munkapont elmozdul, mint minden ilyen jellegü gép vagy szivattyú esetében, tehát ha nincs nagy variáció a sűrítettlevegő-igényben, nem szükséges a szabályozás. Mivel a bányászat ciklikus jellegü és sok minden befolyásolja a sűrítettlevegő-igényt, ez egyfolytában változik.

A bányászat fénykorában a Zsil-völgyi bányák általában turbókompresszorokkal voltak felszerelve. A kiterjedésüktől függően volt olyan bánya, ahol három turbókompresszort is felszereltek. Ezek közül általában kettő működött, amikor a sűrítettlevegő-igény nagy volt, de hétvégén általában csak egyikük üzemelt, mivel ilyenkor nem dolgoztak olyan sokan a bányában.

Ezek általában orosz gyártmányú turbókompresszorok voltak. Egy ilyenfajta turbókompreszszor hét fokozatból áll, három szakaszban elrendezve, az első két szakaszban két forgórész van, az utolsóban pedig három. A hűtést két közbenső hűtő (1. ábra) és egy utolsó hűtő segítségével végezzük, amelyek mindegyike cserélhető.

A műszaki könyv szerinti névleges jellemzők [8]:
Beszívott levegő mennyisége

Szívónyomás

Szívási hőmérséklet

Kimeneti nyomás
$16000 \mathrm{~m}^{3} / \mathrm{h}$;

1 bar;

$20^{\circ} \mathrm{C}$;

8 bar;

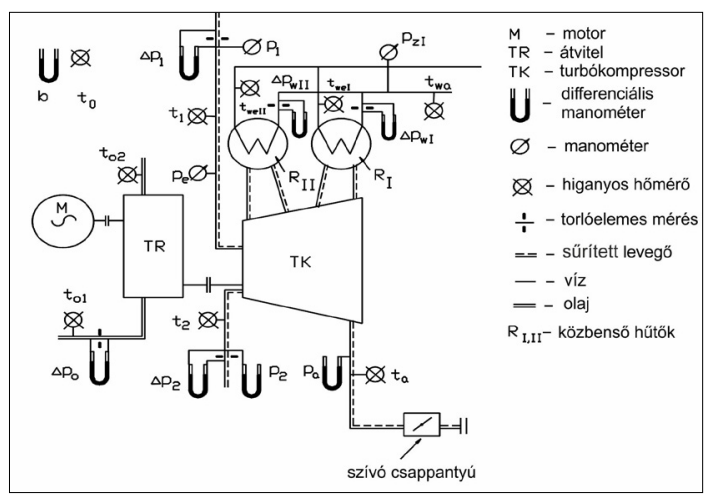

1. ábra. A turbókompresszor felépítése [8]
Turbókompresszor fordulat-

\section{száma}

Motor fordulatszáma

Levegő hőmérséklete a végső

hűtők után

Hűtővíz bemeneti hőmérséklete

Hütővíz áramlása:

- a végső hütőben

- a közbenső hűtőkben

- az olajhűtőben

A hajtómotor névleges teljesít-

ménye

Átvitel hatékonysága

9980 ford./perc;

1500 ford./perc;

$40{ }^{\circ} \mathrm{C}$;

$25^{\circ} \mathrm{C}$

$55 \mathrm{~m}^{3} / \mathrm{h}$;

$95 \mathrm{~m}^{3} / \mathrm{h}$

$20 \mathrm{~m}^{3} / \mathrm{h}$;

$1800 \mathrm{~kW}$;

0,9 ;

0,95 .
Motor hatékonysága

A gyártó által a szállítás előtt elvégzett mérések (1. táblázat) lehetővé tették a turbókompresszor két jelleggörbéjének a megrajzolását, a $\mathrm{p}=\mathrm{f}(\mathrm{Q})$ fojtásgörbét lásd 2. ábra a), és a $\mathrm{P}=\mathrm{f}(\mathrm{Q})$ teljesítmény-jelleggörbéjét 2 . ábra b).

1. táblázat. A gyártó által elvégzett mérések [1]

\begin{tabular}{|c|c|c|}
\hline $\begin{array}{c}\text { Beszívott leve- } \\
\text { gö mennyisége } \\
\text { [m } \mathbf{3} \text { /h] }\end{array}$ & $\begin{array}{c}\text { Kimeneti } \\
\text { nyomás } \\
\text { [bar] }\end{array}$ & $\begin{array}{c}\text { Motor } \\
\text { teljesítménye } \\
\text { [kW] }\end{array}$ \\
\hline 12150 & 10,3399 & 1325 \\
\hline 14000 & 10 & 1525 \\
\hline 16100 & 8,45 & 1570 \\
\hline 17000 & 7,35 & 1555 \\
\hline 17600 & 6,05 & 1510 \\
\hline 18075 & 4,475 & 1442,5 \\
\hline
\end{tabular}

a)
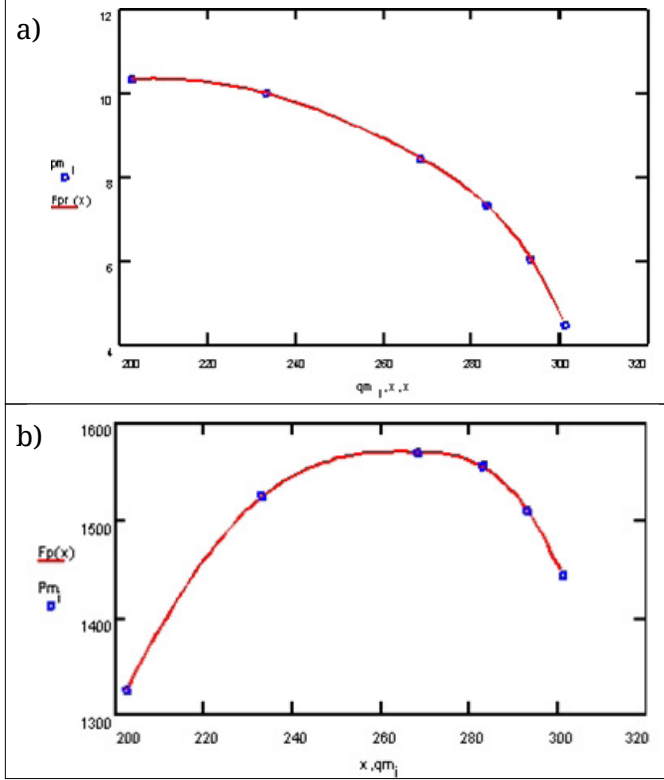

2. ábra. A turbókompresszor jelleggörbéi 
A hűtővíz egy hűtőtoronyba kerül, ahol a levegő segítségével lehűl, utána visszakerül a turbókompresszor hütőibe. Ez a folyamat, általában nyáron, a hütés és a turbókompresszor hatásfokát rosszul befolyásolja, és a sürített levegő túl magas hőmérsékleten kerül a bányába.

\section{A keletkezett hulladékhő mennyisége}

Ahhoz, hogy pontosan ki lehessen számolni a hulladékhő mennyiségét, 124 mérést végeztünk [8].

Az adatok a 3. ábrán vannak feltüntetve.

A hidegebb hónapokban, ebben az esetben márciusban, a víz bemeneti hőmérséklete $15^{\circ} \mathrm{C}$, míg a nyári hónapokban elérheti a $28{ }^{\circ} \mathrm{C}$-t.

A hőmérséklet-emelkedés $2-4{ }^{\circ} \mathrm{C}$, és függ a motor teljesítményétől, ami egyenesen arányos a sűrítettlevegő-igény változásával. A hőmérséklet-emelkedés átlaga $2,75^{\circ} \mathrm{C}$.

A bemeneti hőmérsékletet a hűtőtorony kimeneténél mérték, a kimeneti hőmérsékletet pedig a hűtőtorony bemeneténél, tehát a hűtővíz áramlása ennek megfelelően $170 \mathrm{~m}^{3} / \mathrm{h}$.

A felvett hőmennyiség mértéke:

$$
\begin{aligned}
& Q=m \cdot c \cdot \Delta t=\rho \cdot V \cdot c \cdot \Delta t= \\
& =\frac{997,05 \cdot 170 \cdot 4,1816 \cdot 2,75}{3600}=541,43 \quad \mathrm{~kW}
\end{aligned}
$$

ahol Q - hőmennyiség, kW;

$\mathrm{V}$ - térfogatáram, $\mathrm{m}^{3} / \mathrm{h}$;

$\Delta \mathrm{t}$ - a hőmérséklet változása,

c - a víz fajlagos hőkapacitása $25{ }^{\circ} \mathrm{C}$-on, $\mathrm{kJ} / \mathrm{kg} \cdot \mathrm{K}$,

$\rho-$ a víz fajsúlya, $\mathrm{kg} / \mathrm{m}^{3}$.

Amint látszik, a hulladékhő mennyisége igen nagy, 541,43 kW, és ez mind a környezetbe kerül.

Ezen kívül a nyári időszakban a hűtővíz magas hőmérséklete a turbókompresszor elégtelen hü-

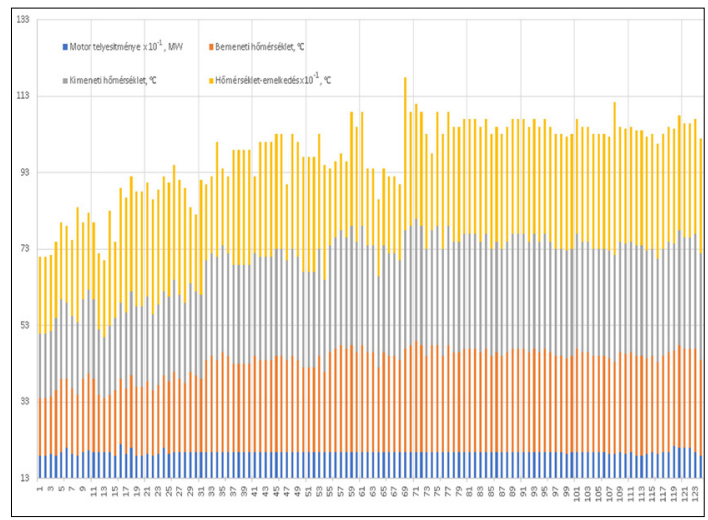

3. ábra. Mért adatok tését eredményezi, ami negatívan befolyásolja a hatásfokát, a forró sűrített levegő pedig emeli a hőmérsékletet a fejtésben, ami rossz hatással van az emberekre.

Tehát két feladatot kell megoldani: egyrészt a hulladékhő hasznosítását, másrészt a turbókompresszor megfelelő hűtését, és mindkettő igen nagy energiamegtakarítással járhat.

A legnagyobb probléma ebben az esetben, a hulladékhő hasznosítása szempontjából abból adódik, hogy a víz hőmérséklete igen alacsony, ezért nem lehet felhasználni úgy, ahogy más technológiai folyamatokban.

\section{A hőszivattyú használata}

Nagy kihívás a hulladékhő hasznosítása folyamatában az, hogy mire is fogjuk használni a viszszanyert hőt. Egy bánya esetében, ahol sok használati meleg vízre van szükség, ennek előállítása a hulladékhő felhasználásával gazdaságos lehet.
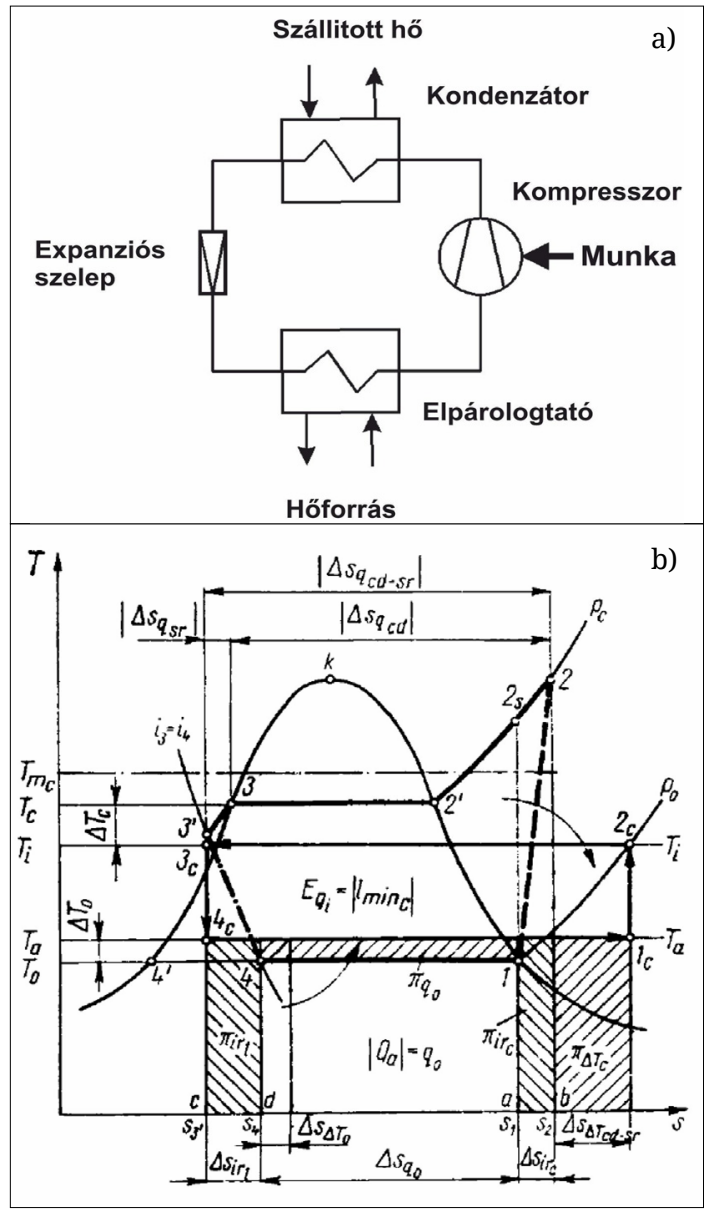

4. ábra. A höszivattyú a) és a körfolyamat b) [9] 
Az alacsony hőteljesítményű energiaforrások kiaknázására alkalmas hőszivattyúk a gőzkompressziós, víz-víz rendszerűek [9]. Ez a típusú hőszivattyú alkalmas arra, hogy $40{ }^{\circ} \mathrm{C}$ alatti hőmérsékleten lévő vízből származó hulladékhőt hasznosítson, a használati meleg vizet $50-80{ }^{\circ} \mathrm{C}$-ra felmelegítve.

Az ilyen hőszivattyú matematikai modelljét a [10] értekezlet keretén belül dolgozták ki, és a továbbiakban ennek a modellnek az alapján számítjuk ki a hőszivattyú hőtani jellemzőit, a következő kezdeti adatok felhasználásával: a szükséges $Q$ hőszállítás, ami legalább annyi kell legyen, mint a hűtővíz által felvett hőmennyiség, $Q=541,43 \mathrm{~kW} ; T_{i}=65{ }^{\circ} \mathrm{C}-\mathrm{a}$ használati meleg víz hőmérséklete; $T_{a}$ - környezeti hőmérséklet (hőforrás); $\Delta T_{c}=5{ }^{\circ} \mathrm{C}-$ a kondenzátor hőátadásához szükséges hőmérséklet-különbség (hőszállítás); $\Delta T_{0}=5{ }^{\circ} \mathrm{C}-$ a párologtató hőátadásához szükséges hőmérséklet-különbség; $T_{s r}=10^{\circ} \mathrm{C}-$ az alulhütéshez szükséges hőmérséklet-különbség; az alkalmazott hűtőközeg R717 (ammónia).

A hőforrás a turbókompresszor hűtőrendszerében felmelegedett víz, így a számításokat a legkisebb, átlag és legnagyobb vízhőmérsékletnek megfelelően végezzük el, ami 16, 26 és $32^{\circ} \mathrm{C}$.

Ezen kívül számításokat kell végezni $5{ }^{\circ} \mathrm{C}$ hőmérsékleten is ahhoz, hogy legyen összehasonlítási alap.

A 2. táblázatban levő adatokat az 5., 6. és 7. ábrákon tüntettük fel.

Ezeken az ábrákon jól látszik, hogy a hőmérséklet emelkedésével csökken a körfolyamat mechanikai munkája és a müködtetéshez szükséges befektetett mechanikai munka mértéke (5. ábra).

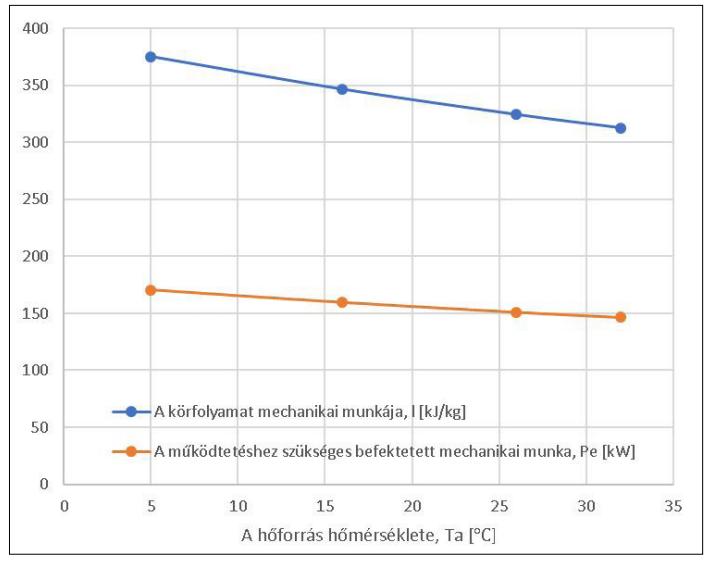

5. ábra. A körfolyamat mechanikai munkája és a müködtetéshez szükséges befektetett mechanikai munka
2. táblázat. A hőszivattyú hőtani jellemzői

\begin{tabular}{|c|c|c|c|c|}
\hline & $\begin{array}{l}\text { Össze- } \\
\text { hason- } \\
\text { lítási } \\
\text { alap }\end{array}$ & $\begin{array}{l}\text { Legki- } \\
\text { sebb } \\
\text { érték }\end{array}$ & $\begin{array}{c}\text { Átlag } \\
\text { hőmér- } \\
\text { séklet }\end{array}$ & $\begin{array}{l}\text { Legna- } \\
\text { gyobb } \\
\text { érték }\end{array}$ \\
\hline $\begin{array}{l}\text { A hőforrás } \\
\text { hőmérséklete, } \\
T_{a}\left[{ }^{\circ} \mathrm{C}\right]\end{array}$ & 5 & 16 & 26 & 32 \\
\hline $\begin{array}{l}\text { A körfolyamat } \\
\text { mechanikai } \\
\text { munkája, } \\
l[\mathrm{~kJ} \cdot \mathrm{kg}-1]\end{array}$ & 375,24 & 346,64 & 324,42 & 312,67 \\
\hline $\begin{array}{l}\text { A működtetés- } \\
\text { hez szükséges } \\
\text { befektetett } \\
\text { mechanikai } \\
\text { munka, } P_{e} \\
{[\mathrm{~kW}]}\end{array}$ & 170,67 & 159,73 & 151,04 & 146,39 \\
\hline $\begin{array}{l}\text { A hőforrásból } \\
\text { (környezetből) } \\
\text { hő formájában } \\
\text { felvett belső } \\
\text { energia, } \\
q_{0} \text { [kJ·kg-1] }\end{array}$ & 947,41 & 958,89 & 967,71 & 972,25 \\
\hline $\begin{array}{l}\text { A felső hőmér- } \\
\text { sékletszinten } \\
\text { leadott hő- } \\
\text { mennyiség, } \\
q_{c}\left[\mathrm{~kJ} \cdot \mathrm{kg}^{-1}\right]\end{array}$ & 1322,65 & 1305,54 & 1292,13 & 1284,92 \\
\hline $\begin{array}{l}\text { Ideális (Carnot) } \\
\text { teljesítményté- } \\
\text { nyező, COP } \mu_{\mathrm{C}}\end{array}$ & 5,64 & 6,9 & 8,67 & 10,25 \\
\hline $\begin{array}{l}\text { Elméleti telje- } \\
\text { sítményténye- } \\
\text { ző, COP } \mu\end{array}$ & 3,52 & 3,76 & 3,98 & 4,11 \\
\hline $\begin{array}{l}\text { Tényleges telje- } \\
\text { sítményténye- } \\
\text { ző, COP } \mu_{\mathrm{e}}\end{array}$ & 3,17 & 3,38 & 3,58 & 3,70 \\
\hline
\end{tabular}

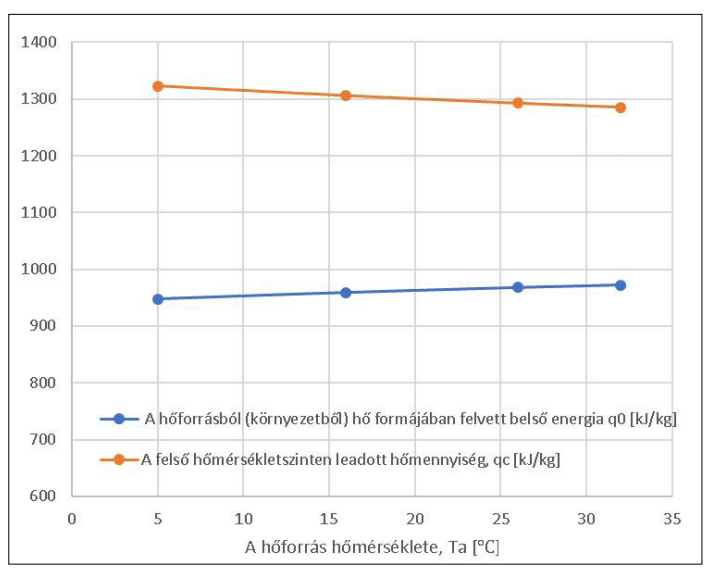

6. ábra. A hőforrásból felvett belső energia és a felső hőmérsékletszinten leadott hőmennyiség 
A 6. ábrán jól látszik, hogy ugyanaz a függőség van a hőforrásból (környezetből) hő formájában felvett belső energia, $q_{0}$ és a hőmérséklet között, míg a felső hőmérsékletszinten leadott hőmenynyiség, $q_{c}$ növekedik a hőmérséklet emelkedésével. A hőszivattyú legfontosabb hőtani jellemzői, az ideális (Carnot) teljesítménytényező, COP $\mu_{\mathrm{C}}$, az elméleti teljesítménytényező, COP $\mu$ és a tényleges teljesítménytényező, COP $\mu_{\mathrm{e}}$, szintén növekedik a hőmérséklet emelkedésével.

\section{Következtetések}

Jelen cikk a turbókompresszor hütéséből keletkező hőmennyiség és annak minősége elemzésére tett kísérletet.

A legnagyobb gondot az jelenti, hogy a keletkezett hő minőségileg nagyon gyenge (alacsony hőmérsékletű), és ezáltal nem lehet közvetlenül felhasználni.

A szakirodalom ilyenfajta hulladékhő hasznosítására a hőszivattyúk használatát ajánlja.

Nagyon sokfajta hőszivattyú létezik mind a konstruktív, mind a hűtőközeg szempontjából, így nehéz lenne őket összehasonlítani. Ezért, az összehasonlítás megkönnyítése érdekében, az alapvető konstruktív modellt, a gőzkompressziós, víz-víz rendszerü, ammóniás hűtőközegű hőszivattyút választottuk.

A hulladékhő mennyisége igen nagy, 541,43 kW, pedig csak egyetlen turbókompresszor által termelt hőről van szó. Ha ezt az érteket megszorozzuk tízzel (mivel átlagban ennyi turbókompreszszor működött a helyi bányaiparban), a felhasználható hő mennyisége igen nagy, és elég lenne

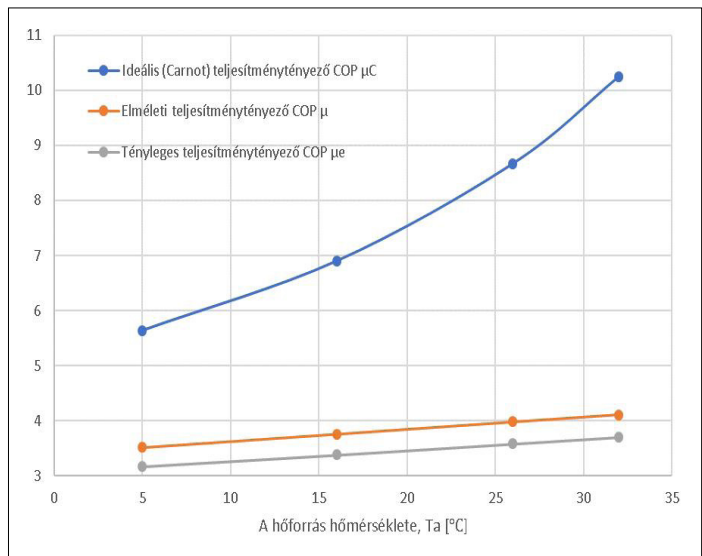

7. ábra. Az ideális (Carnot) teljesítménytényező, az elméleti teljesítménytényező és a tényleges teljesítménytényezö COP egy kisebb település fütésére, tehát érdemes foglalkozni ennek hasznosításával.

A hőszivattyú használata nagyon jól beválik a hulladékhő hasznosítására, mivel a tényleges teljesítménytényező, COP $\mu_{\mathrm{e}}$ nagyon magas, és tovább nő a hulladékhő hőmérsékletének emelkedésével.

Bár a nagy mennyiségű hulladékhő hasznosítása nem jelent problémát technikai szempontból, meglehet, hogy gazdasági szempontból nem válik be, mivel olyan fogyasztót kell találni, aki felhasználja ezt a folyamatosan keletkező hőmennyiséget.

Ennek a hőmennyiségnek a tárolását nem igazán lehet gazdaságosan megoldani. Gondot okoz a szállítása is, hisz a bányák általában a településeken kívül, jobb esetben a helységek szélén helyezkednek el.

A hőszállítás távvezetékeken keresztül valósulhatna meg, víz hőhordozó közeg felhasználásával, bár ennek kiépítése nagy költségekkel járna.

Megoldást jelenthetne a meglévő távfütés csőrendszerébe csatlakozni, de ebben az esetben több technikai gond is felmerül, ugyanis a hőhordozó hőmérséklete és nyomása olyan szinten kell legyen, hogy ne okozzon zavart a már kiépített távfütési rendszerben.

\section{Szakirodalmi hivatkozások}

[1] European Commission, Energy Efficiency.

https://ec.europa.eu/energy/en/topics/energy-efficiency/targets-directive-and-rules/energy-efficiency-directive (letöltve: 2019. szeptember 24.)

[2] United States Environmental Protection Agency. https://www.epa.gov/energy/national-action-plan-energy-efficiency (letöltve: 2019. szeptember 24.)

[3] Magyarország Kormánya, Nemzeti Fejlesztési Minisztérium (letöltve: 2019. szeptember 24.)

https://2010-2014.kormany.hu/download/4/f8/ 70000/Nemzeti\%20Energiastrat\%C3\%A9gia\%20 2030\%20teljes\%20v\%C3\%A1ltozat.pdf

[4] Guvernul României. Ministerul Energiei.

http://energie.gov.ro/transparenta-decizionala/strategia-energetica-a-romaniei-2019-2030-cu-perspectiva-anului-2050/ (letöltve: 2019. szeptember 24.)

[5] Goverment of India, Bureau of Energy Efficiency. https://beeindia.gov.in/sites/default/files/2Ch8. pdf (letöltve: 2019. szeptember 24.)

[6] U.S. Department of Energy. https://www.energy.gov/eere/amo/articles/wasteheat-recovery-resource-page (letöltve: 2019. szeptember 24.) 
[7] U.S. Department of Energy. Industrial Technologies Program. (letöltve: 2019. szeptember 24.) https://www1.eere.energy.gov/manufacturing/intensiveprocesses/pdfs/waste_heat_recovery.pdf

[8] Dosa I.: Research on energetics of thermal and fluid dynamic processes in mining pneumatic installations. Ph. D. thesis in Engineering; Specialty: Mining machines and installations. University of Petroșani, 1999.
[9] Radcenco V.: Procese în instalații frigorifice. Editura Didactică și Pedagogică, București, 1983. 372-390.

[10] Dosa I.: Power Plant Waste Heat Recovery for Household Heating Using Heat Pumps. University of Petrosani, Multiscience-XXVIII. microCAD International Multidisciplinary Scientific Conference, Miskolc, 10-11 april 2014. 